\title{
Evaluation of an OBCE Conversion Contract in a Large-scale Oil and Gas Project
}

\author{
Ruveyda Komurlu', and Akin $\mathrm{Er}^{2 *}$ \\ ${ }^{1}$ Department of A rchitecture, Kocaeli U niversity, K ocaeli, Turkey \\ ${ }^{2}$ TUPRAS General M anagement, Kocaeli, Turkey
}

\begin{abstract}
Billion-dollar investments are quite common in oil and gas industry and owners generally prefer engineering, procurement, construction (EPC) contracts since they would like to minimize their risks and guarantee the most consistent project cost and shortest timeline scheme. Considering the size of contracts, owners are unsurprisingly seeking an ideal tender awarding method to avoid deviation from project schedule or budget and get the maximum benefit for them. They may prefer to award the EPC contract directly (i), have a front-end engineering design (FEED) study done first and award the EPC contract afterwards (ii), or set up a convertible contract and convert it to EPC after an open book cost estimate (OBCE) process (iii). It is a question of concern which option for large-scale oil and gas projects is the most favourable. As a case study, outcomes of a project which was administrated with a conversion type of contract will be reviewed in detail, and a number of principles based on lessons learned will be listed. Thus, the authors aim to provide a verifying approach for the interpretation of EPC conversion type contract management based on analysis of the distinguishing features of large-scale oil and gas projects.
\end{abstract}

Keywords: convertible contracts, FEED study, EPC contracts, OBCE (open book cost estimate), oil and gas projects.

\section{Introduction}

Oil and gas companies should invest in several projects every year. This is inevitable for them as there are so many forcing factors like new environmental regulations, operational requirements, modernization, renovation, profitability, etc. Some of these projects cost more than billion-dollars. Considering the negative consequences of mistakes that could be made during the investment period of such projects, owners are unsurprisingly investigating for the correct contract strategy which fits well with their project objectives.

In general, contract strategy refers to organizational and contractual policies which are selected for the execution of a specific project [1]. It is one of the key parameters which has significant effects on the project. Risk allocations of project actors, namely owner, contractor

* Corresponding author: akin.er@tupras.com.tr 
and vendor, are tightly linked to that decision given by the owner at the beginning of the project. Tendering process, responsibilities, interfaces between phases, management policies are all evolved around that decision which certainly means that contract strategy has also an important impact on the project schedule and the budget [2].

This article will primarily focus on contract strategies which could be followed during a project. After making an overview of the characteristics of large scale projects in oil and gas, EPC lump sum type contracts will be reviewed individually. Different methods of EPC contract will be discussed. Finally, an implementation of a conversion type EPC contract will be evaluated as support for theoretical conclusions. By this way, it is aimed at an approach to verify the interpretation of EPC conversion type contract management will be provided.

\section{Overview of Contract Strategies}

\subsection{Main Components of Contract Strategy}

Contract strategy shapes the management decisions of all parties in the project. It basically depends on three main components namely project delivery method, contract price arrangement and contract clauses [3].

\subsubsection{Project Delivery Method}

Project delivery method determines the sharing of responsibilities of each project phase between the parties of the contract. There are four types of project delivery methods [3]:

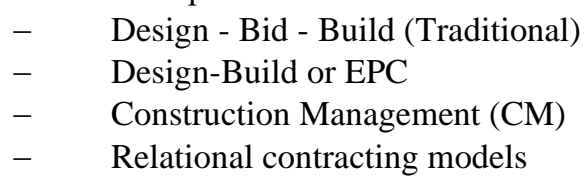

Design - Bid - Build, Design-Build and Construction Management methods are compared in Table 1.

Table 1. Comparison of Project Delivery M ethods

\begin{tabular}{|c|c|c|c|}
\hline & Design - Bid - Build & Design-Build or EPC & $\begin{array}{c}\text { Construction } \\
\text { Management (CM) }\end{array}$ \\
\hline $\begin{array}{c}\text { Basic } \\
\text { characteristics }\end{array}$ & $\begin{array}{l}\text { - Separate design and } \\
\text { construction contracts } \\
\text { - B idding is after the design } \\
\text { is completed }\end{array}$ & $\begin{array}{l}\text { - A single contract that } \\
\text { consists of engineering, } \\
\text { procurement and } \\
\text { construction } \\
\text { - Enables to overlap } \\
\text { project phases }\end{array}$ & $\begin{array}{l}\text { - A designated contractor } \\
\text { performs construction } \\
\text { management on behalf } \\
\text { of the owner }\end{array}$ \\
\hline Advantages & $\begin{array}{l}\text { - Project scope and } \\
\text { procedures are well defined } \\
\text { before construction } \\
\text { - Changes during design } \\
\text { development have no } \\
\text { significant cost impact }\end{array}$ & $\begin{array}{c}\text { - Transfer risk to the } \\
\text { contractor } \\
\text { - The shortest path for the } \\
\text { project duration } \\
\text { - Project cost is } \\
\text { determined at an early } \\
\text { stage }\end{array}$ & $\begin{array}{l}\text { - Enables the owner to set } \\
\text { up a smaller organization }\end{array}$ \\
\hline Disadvantages & $\begin{array}{l}\text { - The owner takes the } \\
\text { coordination and risk } \\
\text { - The longest path for the } \\
\text { project duration } \\
\text { - Project cost is not definite } \\
\text { at the beginning }\end{array}$ & $\begin{array}{c}\text { - Owner's control is } \\
\quad \text { limited } \\
\text { - Requires more qualified } \\
\text { and expensive contractors }\end{array}$ & $\begin{array}{l}\text { - Additional cost due to } \\
\text { CM } \\
\text { - Decisions can be more in } \\
\text { favour of counterparties } \\
\text { compared to the owner's } \\
\text { direct involvement }\end{array}$ \\
\hline
\end{tabular}


The relational contracting model also offers a contract to represent a relationship between the parties. However, unlike the other three models, it introduces a degree of flexibility into the contract on the basis of understanding the other party's objectives [4]. By this way, all project participants intend to work as one integrated team in the project from the design stage until completion [5]. Alliance, IPD (Integrated Project Delivery) and project partnering contracts could be listed in this group.

\subsubsection{Contract Price Arrangements}

Provision of the contract price is another component of the contract strategy. It could be classified into three main categories in view of some studies $[2,6]$ about the subject.

- $\quad$ Price Based Contracts

- Cost-Based Contracts

- Guaranteed M aximum Price Contracts

Price Based Contracts, Cost-Based Contracts and Guaranteed Maximum Price Contracts are compared in Table 2 .

Table 2. Comparison of Contract Price A rrangements

\begin{tabular}{|c|c|c|c|}
\hline & Price Based Contracts & $\begin{array}{l}\text { Cost Based } \\
\text { Contracts }\end{array}$ & $\begin{array}{l}\text { Guaranteed Maximum } \\
\text { Price Contracts }\end{array}$ \\
\hline $\begin{array}{c}\text { Basic } \\
\text { characteristics }\end{array}$ & $\begin{array}{l}\text { - Prices are agreed in the } \\
\text { contract } \\
\text { - Costs are unknown by } \\
\text { the owner } \\
\text { - Preferred when scope or } \\
\text { design are well defined }\end{array}$ & $\begin{array}{l}\text { - The contractor is } \\
\text { reimbursed for all costs } \\
\text { plus fee } \\
\text { - Costs are known by the } \\
\text { owner } \\
\text { - Preferred when scope } \\
\text { or design is not mature }\end{array}$ & $\begin{array}{l}\text { - Combination of price } \\
\text { and cost-based contracts } \\
\text { - The contractor is } \\
\text { reimbursed up to a } \\
\text { maximum fixed amount }\end{array}$ \\
\hline Types & $\begin{array}{l}\text { - U nit Price } \\
\text { (A dmeasurement) } \\
\text { - Fixed Price (Lump sum) }\end{array}$ & $\begin{array}{l}\text { - Cost-plus ratio of cost } \\
\text { - Cost-plus fixed fee } \\
\text { - Cost-plus incentive fee }\end{array}$ & \\
\hline Payment Types & $\begin{array}{l}\text { - U nit Price - time } \\
\text { intervals } \\
\text { - Fixed Price-time } \\
\text { intervals or achieved } \\
\text { milestones }\end{array}$ & - Time intervals & - Time intervals \\
\hline $\begin{array}{c}\text { Advantages / } \\
\text { Disadvantages }\end{array}$ & $\begin{array}{l}\text { - Unit Price - Total price } \\
\text { is not known since it is } \\
\text { related to actual quantities } \\
\text { - Fixed Price-Total price } \\
\text { is known, risks are } \\
\text { transferred to the } \\
\text { contractor }\end{array}$ & $\begin{array}{l}\text { - M ore flexible } \\
\text { - Risks are on the owner }\end{array}$ & - Shared risks \\
\hline
\end{tabular}

\subsubsection{Contract Clauses}

Contract clauses principally adjust general responsibilities of parties during the execution of the project. The main body of contracts usually describes basic matters of the project like parties, reference documents, scope, price, time for completion, bonus and penalties. 
A general and special condition of contracts typically explains definitions, guarantees and liabilities, risk distributions and details of work execution. Owners should define contract clauses considering their contract strategy.

\subsection{Parameters Designated Contract Strategy}

Although some projects have almost the same scopes, it should be recognized that each project is unique since it has its own conditions, constraints or opportunities. Thus, taking into account some key factors, owners should determine the contract strategy specifically for each project. Those key factors could be listed as follows [7]:

- $\quad$ Risk allocation between owner and contractor

- $\quad$ Type, location and size of the project

- $\quad$ Division of responsibilities between parties

- $\quad$ Interfaces between project phases

- M Market situation

- $\quad$ Splitting of works and services between concerned parties

- $\quad$ Project time constraints

- Owner's existing organization and resources

Legal regulations, qualifications of potential contractors, availability of specific construction equipment and payment method [8] could be also added to the listed factors above. Hence, owners should evaluate their resources, objectives and project characteristics before deciding their contract strategy.

\section{Characteristics of Large-Scale Oil and Gas Projects}

\subsection{Project Development Stages}

A large-scale oil and gas project should pass various stages (Figure 1) which begin with idea generation and ends with an operational start-up. The first four stages express the maturity of the project, whereas the last two are the implementation of the project. The end of the first four stages are called decision gates where project cost estimates should be updated and investment feasibilities should be reassessed.

\begin{tabular}{|c|l|l|l|l|l|}
\hline \multicolumn{3}{|c|}{ Maturity of Project } & \multicolumn{2}{c|}{ Implementation of Project } \\
\hline $\begin{array}{c}\text { Idea } \\
\text { Generation }\end{array}$ & $\begin{array}{c}\text { Conceptual } \\
\text { Design }\end{array}$ & \multicolumn{1}{|c|}{$\begin{array}{c}\text { Basic } \\
\text { Engineering }\end{array}$} & FEED & Project Execution & $\begin{array}{l}\text { Commissioning } \\
\text { \& Start-up }\end{array}$ \\
\hline & $\begin{array}{l}\text { Pre- } \\
\text { feasibility }\end{array}$ & Feasibility & $\begin{array}{l}\text { Part of } \\
\text { Detailed } \\
\text { Engineering }\end{array}$ & $\begin{array}{l}\text { Detailed } \\
\text { Engineering } \\
\text { Procurement } \\
\text { Construction }\end{array}$ & \\
\hline GATES & &
\end{tabular}

Fig. 1. Project Stages 


\subsection{Fast Track Execution}

Project execution stage consists of three main phases i.e. detailed engineering, procurement and construction. Each phase requires several months to be completed. Hence, the project duration of those projects lasts much more than many other construction projects. However, owners want to put their projects into operation quickly because they want the return of their considerable investments as soon as possible. To shorten the duration of the execution period such phases should be overlapped. Therefore, large-scale oil and gas projects are fast track projects. However, this approach also brings the risks of revision and rework.

\begin{tabular}{|c|c|c|c|c|c|}
\hline Traditional Project Execution & & & & & \\
\hline - Project M aturity Period & & & & & \\
\hline - Detailed Engineering & & & & & \\
\hline - Procurement & & & & & \\
\hline - Construction & & & & 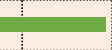 & \\
\hline - Commissioning \& Start-up & & & & & 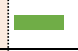 \\
\hline Fast Track Project Execution & & & & & \\
\hline - Project M aturity Period & & & & & \\
\hline - Detailed Engineering & & & & aved & \\
\hline - Procurement & & 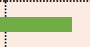 & & ime & \\
\hline - Construction & & & 4 & $\longrightarrow$ & \\
\hline - Commissioning \& Start-up & & & 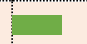 & & \\
\hline
\end{tabular}

Fig. 2. Fast Track Project Execution

\subsection{Estimation Range of CAPEX}

Accuracy of CAPEX is another important point in those projects. It directly affects the financial parameters of the investment (e.g. net present value, internal rate of return) and has a significant role at the investment decision. Thus, owners would like to know CAPEX with a certain degree of accuracy before the commencement of the project execution. However, due to the aforementioned facts, the accuracy of the project cost is a question mark for decision-makers. AACE 18R-97 [9] recommends five estimate classes and corresponding accuracy ranges regarding the maturity level of project deliverables. 
Table 3. A A CE Cost Estimate Classification [9]

\begin{tabular}{|c|c|c|c|c|c|c|c|c|}
\hline \multicolumn{8}{|c|}{ AACE Recommended Practice - 18R-97 } & \multirow{3}{*}{$\begin{array}{l}\text { Corresponding } \\
\text { Project Stage } \\
\text { Conceptual Design }\end{array}$} \\
\hline $\begin{array}{l}\text { Estimate } \\
\text { Class }\end{array}$ & \multicolumn{3}{|c|}{$\begin{array}{l}\text { M aturity Level of } \\
\text { Deliverables }\end{array}$} & \multicolumn{4}{|c|}{ Expected A ccuracy Range } & \\
\hline Class 5 & $0 \%$ & To & $2 \%$ & $\begin{array}{l}\mathrm{L}: \\
\mathrm{H}:\end{array}$ & $\begin{array}{l}-20 \% \\
+30 \%\end{array}$ & $\begin{array}{l}\text { to } \\
\text { to }\end{array}$ & $\begin{array}{l}-50 \% \\
+100 \%\end{array}$ & \\
\hline Class 4 & $1 \%$ & To & $15 \%$ & $\begin{array}{l}\mathrm{L}: \\
\mathrm{H}:\end{array}$ & $\begin{array}{l}-15 \% \\
+20 \% \\
\end{array}$ & $\begin{array}{l}\text { to } \\
\text { to }\end{array}$ & $\begin{array}{l}-30 \% \\
+50 \% \\
\end{array}$ & $\begin{array}{c}\text { Basic Design or } \\
\text { Early Stage of FEED }\end{array}$ \\
\hline Class 3 & $10 \%$ & To & $40 \%$ & $\begin{array}{l}\mathrm{L}: \\
\mathrm{H}:\end{array}$ & $\begin{array}{l}-10 \% \\
+10 \%\end{array}$ & $\begin{array}{l}\text { to } \\
\text { to }\end{array}$ & $\begin{array}{l}-20 \% \\
+30 \%\end{array}$ & FEED \\
\hline Class 2 & $30 \%$ & To & $75 \%$ & $\begin{array}{l}\mathrm{L}: \\
\mathrm{H}:\end{array}$ & $\begin{array}{l}-5 \% \\
+5 \%\end{array}$ & $\begin{array}{l}\text { to } \\
\text { to }\end{array}$ & $\begin{array}{l}-15 \% \\
+20 \% \\
\end{array}$ & $\begin{array}{c}\text { Final Stage of FEED or } \\
\text { Project Execution }\end{array}$ \\
\hline Class 1 & $65 \%$ & To & $100 \%$ & $\begin{array}{l}\mathrm{L}: \\
\mathrm{H}:\end{array}$ & $\begin{array}{l}-3 \% \\
+3 \% \\
\end{array}$ & $\begin{array}{l}\text { to } \\
\text { to }\end{array}$ & $\begin{array}{l}-10 \% \\
+15 \% \\
\end{array}$ & Project Execution \\
\hline
\end{tabular}

\subsection{Complexity}

Large-scale oil and gas projects are complex projects since they are multi-discipline and multi-phase projects. Fast track execution creates interfaces between phases due to overlapping and brings management difficulties like other types of projects carried out in this way. Multiple contractors, financing scheme, etc. are some other factors that may increase the complexity. Owner's contract strategy determines the degree of complexity and the required level of management organization.

\subsection{Cost of Design Changes}

Several key design decisions are given by the owners during project development. However, the cost of change could be significantly high in large-scale oil and gas projects. The relative cost of making a design change in the various phases of such a project has been stated in Table 4 [10].

Table 4. Relative Cost of $M$ aking a D esign Change

\begin{tabular}{|c|c|c|}
\hline Phase & Impact & Relative Cost (USD) \\
\hline $\begin{array}{c}\text { Process Design Package } \\
\text { Basic Engineering }\end{array}$ & tens of engineering hours & Thousands \\
\hline Detailed Engineering & hundreds of engineering hours & tens of thousands \\
\hline Sourcing & thousands of engineering hours & hundreds of thousands \\
\hline Construction & $\begin{array}{c}\text { engineering, construction time, } \\
\text { equipment }\end{array}$ & Millions \\
\hline Post-Start-up & $\begin{array}{c}\text { engineering, equipment, } \\
\text { installation }\end{array}$ & millions to tens of millions \\
\hline
\end{tabular}

\section{EPC Contracting Methodologies}

Considering the characteristics of large-scale oil and gas projects, EPC lump-sum contracting appears as the most advantageous strategy for the owners. Because it ensures to owners not the least but the most reliable budget and minimum risk. Fast track execution enables to complete the project in the shortest duration. Owners could manage the project with a smaller organization compared to alternative strategies. On the other hand, some 
disadvantages of the strategy could be mentioned such as maximum contingency in the contract price and less involvement of the owner in the detailed design. Nevertheless, considering benefits of the aforesaid advantages, owners widely prefer EPC lump sum for the execution period of their projects.

It is possible to follow different methodologies while awarding an EPC contract. Owners may prefer to award the EPC contract directly (i), have a front-end engineering design (FEED) study done first and award the EPC contract afterwards (ii), or set up a convertible contract and convert it to EPC after an open book cost estimate process (iii). Last two methodologies have been developed to minimize the disadvantages of EPC contracting in the course of time.

In case of a direct EPC contracting, the owner defines the project frame and assigns a contractor to follow all engineering, procurement and construction activities of it. The role of the owner is mainly limited to project controls and contract management. The contractor bears the risks and responsibilities. Therefore, the contract price includes maximum contingency. If the project frame was not clearly defined in the bidding document, possible design changes might result in significant change orders. However, the project duration will be the minimum.

In order to minimize aforesaid drawbacks, owners may prefer to have a FEED contract first and award the EPC contract afterwards. By this way, design development will reach a reasonable level of maturity before EPC contracting. Project cost could be estimated more precisely since long lead items become ready for purchase orders and quantities could be reckoned pretty close to exact figures. Cost deviation is inversely proportional to the level of information. However, this methodology requires two awarding periods both for FEED and EPC. In the second awarding, if the EPC contractor is selected different than the FEED contractor, that will create a discontinuity in the detailed engineering. In this case, some owners may request from the EPC contractor to process existing detailed engineering document once again which results in additional time and money.

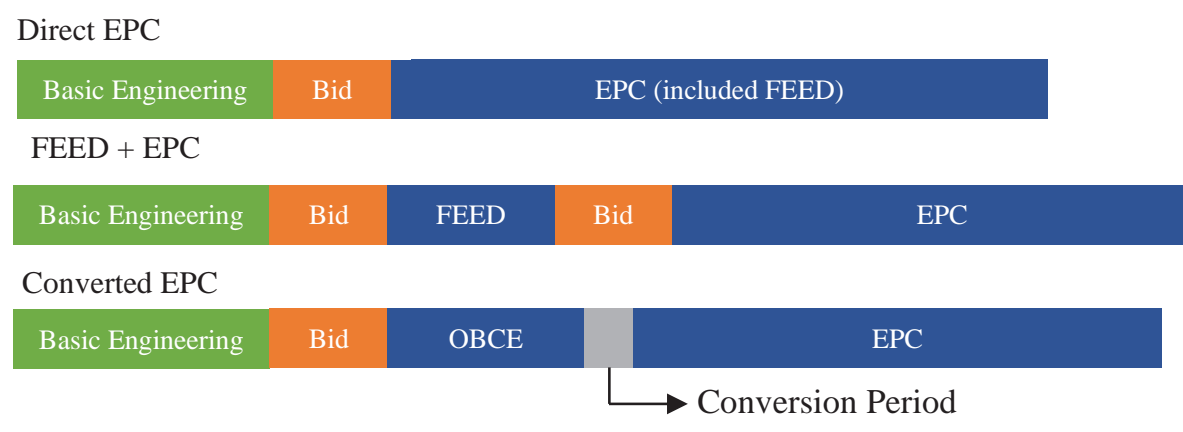

Fig. 3. EPC Contracting M ethodologies

Convertible contracts prevent the discontinuity of FEED plus EPC contracts. In this method, the owner and the contractor agree on a two-stage contract. In the first stage, detailed design is advanced up to a certain level where project cost could be calculated reasonably accurate. Cost estimation study should be transparent and traceable for the owner. The process is called as OBCE (open book cost estimate). In this stage, the contractor could be paid in any price adjustment structure. Later on, the contract is converted into EPC lump sum following the conversion method previously defined in it. By this way, all project costs, contingency amount and the contractor's profit are all known by the owner. Moreover, the contractor could proceed to the second stage immediately and uninterruptedly after the 
conversion. As the final outcome of the above comparison, it can be concluded that convertible contracts solve most of the concerns of a project.

\section{Implementation of an OBCE Conversion Contract}

Resid Upgrading Project has been executed in TUPRAS Izmit Refinery-Turkey. It is a typical sample of large-scale oil and gas projects which consist of civil works, steelworks, piping, equipment erection, electrical works, instrumentation etc., thus require coordination of various sub-contractors for the success of the project [11]. The total cost of the project is 2.7 billion dollars including financial expenditures. Basic engineering of the main three units was completed prior to the bidding stage. EPC package was including basic engineering of smaller units and detailed engineering, procurement, construction of the complete project. Owner's preference was direct EPC awarding methodology in the previous large-scale projects. However, considering the size of the package and level of information for bidders, it was anticipated that the contingency amount in the tenders could be extremely high. Thus, an OBCE conversion contract has been implemented in the project.

Timeline of the project is shown in Figure 4. The project was divided into two stages namely OBCE Period and Project Execution Period (EPC). There is a two months conversion period between two stages, in which OBCE calculations were rechecked and an EPC contract was put into final form. However, an extra four months have been spent to finalize for financial agreements due to creditors involvement that was not forecasted at the initial planning. The two stages, i.e. OBCE and EPC, were clearly defined in the contract. The contract gave the right to TUPRAS not to continue the project after the OBCE stage. By this way, the last decision gate was kept in the contract.

Contract price adjustment was set on a fixed price for both the OBCE and the EPC stages. The total project cost has been separated into five categories; detailed engineering, itemized materials (equipment), bulk material, construction and ancillary costs (transportation, customs, insurance, training services, etc.). A lump sum price was agreed for detailed engineering considering the OBCE and the EPC stages separately. For other categories, contractor's fee and allowance ratios were agreed in the contract which was necessary for the conversion.

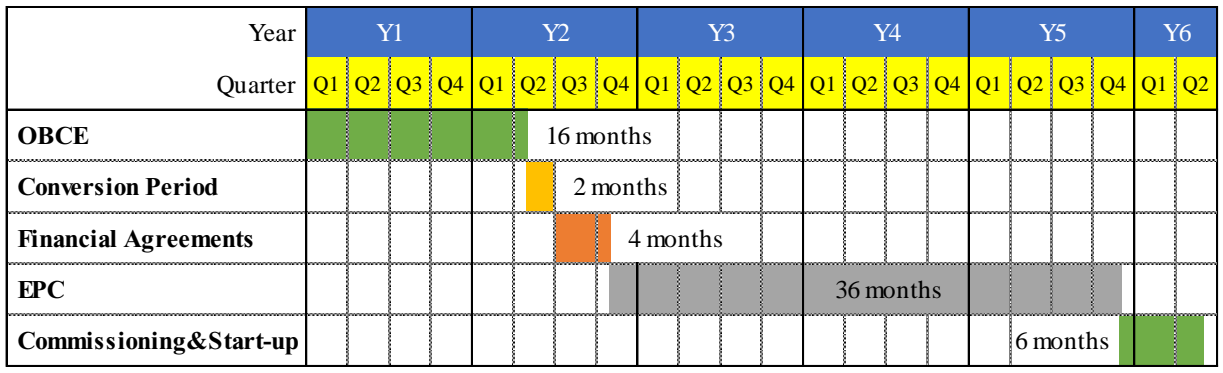

Fig. 4. Timeline of Resid U pgrading Project

Contractor's fee corresponds to the profit overestimated cost and they are proposed by the contractor for each cost category during the bid. However, allowance ratios are defined by TUPRAS in the bidding document to cover some potential costs of the contractor which could not be foreseen during the OBCE studies. Allowance ratio was between 3\% and 5\% in this project, and was defined to cover items listed below:

- $\quad$ Increments in quantities that may occur due to detailed design development after the conversion, 
- $\quad$ Small design changes due to construction requirements at the site,

- Consumables that could not be included in quantities,

- Wastes due to the nature of manufacturing or construction activities,

- Normal levels of rework due to construction errors, bad welds, and incorrect installations,

- $\quad$ Lost, damaged or broken materials.

Itemized materials correspond to equipment which is defined in the basic engineering design packages. Those equipment were grouped in order to define purchase order packages according to their types and properties. The contractor collected a minimum of three bids for each PO packages from the vendors which were listed by TUPRAS in the contract. Bids were transparently opened and evaluated with the participation of both parties and that procedure has been applied to $98 \%$ equipment during the OBCE. Moreover, for long-lead items, vendors were called to face to face meetings, and after technical and commercial negotiations, awarded bids were decided. TUPRAS sent letters of intent to awarded vendors on behalf of the contractor and fixed the price for the project's execution period. Regarding bulk material, bids were requested in the unit price base. The total cost has been calculated according to the bill of quantities taking into account the detailed engineering document developed until the end of OBCE studies.

Construction cost was also studied in the unit price base. The project was divided into seven construction packages. Bill of quantities of each package has been calculated according to the developed detailed engineering document. Awarding stage has been conducted with the participation of both parties. Also, final negotiations have been done in this category and subcontractors were agreed for each construction package prior to the conversion.

Ancillary costs were determined in several ways. The method of collecting bids was preferred upmost. If it is not possible to use such a method, in-house data of both parties and rule of thumbs were used.

A complete file including all OBCE studies has been issued at the beginning of conversion period. All data have been reviewed again together by both parties. Total lump sum price of the project has been calculated as shown in Table 5. Finally, opportunities which could decrease the total price were discussed by the management of the parties and the lump sum EPC price was determined.

Table 5. Simple Illustration of L ump Sum Conversion Calculation

\begin{tabular}{|c|c|c|c|c|}
\hline $\begin{array}{c}\text { COST } \\
\text { CATEGORIES }\end{array}$ & OBCE & Allowance & Fee & Converted Cost \\
\hline Detailed Engineering & - & - & - & $\mathrm{CC} 1=\mathrm{L}$ ump sum price \\
\hline Itemized M aterials & $\mathrm{C} 2$ & $\mathrm{a}_{2} \%$ & $\mathrm{~F}_{2} \%$ & $\mathrm{CC} 2=\mathrm{C} 2 \times\left(1+\mathrm{a}_{2} \%+\mathrm{F}_{2} \%\right)$ \\
\hline Bulk M aterial & $\mathrm{C} 3$ & $\mathrm{a}_{3} \%$ & $\mathrm{~F}_{3} \%$ & $\mathrm{CC} 3=\mathrm{C} 3 \times\left(1+\mathrm{a}_{3} \%+\mathrm{F}_{3} \%\right)$ \\
\hline Construction & $\mathrm{C} 4$ & $\mathrm{a}_{4} \%$ & $\mathrm{~F}_{4} \%$ & $\mathrm{CC} 4=\mathrm{C} 4 \times\left(1+\mathrm{a}_{4} \%+\mathrm{F}_{4} \%\right)$ \\
\hline Ancillary Costs & $\mathrm{C} 5$ & $\mathrm{a}_{5} \%$ & $\mathrm{~F}_{5} \%$ & $\mathrm{CC} 5=\mathrm{C} 5 \times\left(1+\mathrm{a}_{5} \%+\mathrm{F}_{5} \%\right)$ \\
\hline \multicolumn{2}{|r}{} & $\mathrm{SUM}=$ Total Project Price \\
\hline
\end{tabular}

Regarding the EPC stage, the project was completed on time and on budget. This is one of the results of good preparation and planning conducted during the OBCE period. Commissioning \& start-up periods were also accomplished successfully. However, an extra four months have been spent before the commencement of EPC to finalize the financial agreement which is not generally forecasted in such kind of projects at the beginning. This should be noted as a learning outcome from the project. 


\section{Conclusions}

EPC convertible contracts enable the owner to optimize the combination of some important project parameters such as initial cost, change order ratio, duration of the project and management organization. Therefore, it becomes a preferred contracting method for largescale oil and gas projects in recent decades. This method could be utilized in other sectors with similar characteristics and constraints, such as mining, IT etc., where the cost of largescale projects could not be estimated efficiently at the bidding stage.

Successful implementation has been applied in TUPRAS Izmit Refinery Resid Upgrading Project. Regarding the lessons learned from that project key principles for future use are advised as below:

- OBCE studies should be done in a transparent manner with the participation of the owner and the contractor.

- The owner should define the procedure clearly which should be followed during OBCE studies and conversion calculation in the bidding document.

- The owner should have a compact but experienced project team. Commercial evaluations should be done regarding the recent development of engineering studies and technical evaluations. Thus, an OBCE coordinator should be assigned to synchronize both commercial and technical groups.

- $\quad$ V endor list should be included in the contract by the owner. If the contractor proposes a new vendor, it must be up to the owner's consent.

- $\quad$ Engineering should reach a certain level of progress before the conversion for a clear scope definition and reasonable accuracy of quantity calculation. That progress figure is suggested as $50 \%$ to $60 \%$ [12].

However, regarding the Resid Upgrading Project, engineering progress of $40 \%$ to $45 \%$ seems reasonable for the conversion. The figures below show the engineering progress of the project at the time of the conversion:

Engineering Services:

\begin{tabular}{ll}
\hline Detailed Engineering & $43,21 \%$ \\
\hline Procurement Services & $61,29 \%$ \\
\hline Home-Office Construction Services & $70,00 \%$ \\
\hline W eighted Progress of Eng. Services & $45,30 \%$
\end{tabular}

- $\quad$ Final negotiations with vendors and subcontractors should be done after the purchase order packages reach a certain level maturity.

- $\quad$ The total cost of categories should be reported periodically during OBCE studies. By this way, the content of the final OBCE report could be established prior to the conversion period with the consent of both parties which may help to shorten the conversion process significantly.

It is hoped that these findings may be applied in other similar projects regardless of the industry, and it helps improve the efficiency of EPC contracts.

\section{References}

1. E. Ebeltagi, Construction project management. Lecture $\mathrm{N}$ otes, M ansoura University, Department of Structural Engineering, Egypt (2009)

2. D. B ower, Management of procurement (Thomas Telford, L ondon, 2003) 
3. M. Moazzami, R. Deghan, G. Jergeas, J. Ruwanpura, A theoretical framework to enhance the conversion process in convertible contracts, International Journal of Construction Engineering and Management 4(6), 248-262 (2015)

4. N. Faisol, A.R.J. Dainty, A.D.F. Price, The concept of celational contracting cas a tool for understanding inter-organizational relationships in construction, Procs 21st Annual Association of Researchers in Construction Management Conference, Vol. 2: 10751084 (2005)

5. Y. Salamah, Alliance contracting models in construction projects: leadership and management, Master Thesis, Metropolia University of Applied Science, Helsinki, Finland (2017)

6. E.R. Fisk, W.D. Reynolds, Construction project administration (Pearson Education, New J ersey, 2014)

7. C. Schramm, A. M eissner, G. Weidinger, Contracting Strategies in the oil and gas industry, 3R International, Special Edition, 1/2010: 33-36 (2009)

8. M. Ducros, G. Fernet, Project management guide (Editions Technip, Paris, 2010)

9. AACE International Recommended Practice No.18R-97, Cost estimate classification system - as applied in engineering, procurement and construction for the process industry (2006), https://web.aacei.org/resources/publications/recommended-practices

10. M. Fenton, K. A rmstrong, J. Huebsch, Convertible lump sum EPS contracting model how to get the plant you need now and still enjoy in 20 years?, Procedia Engineering 138: 206-219 (2016)

11. A . Er, R. K omurlu, Importance of Planning in Refinery Projects and Recommendations for Successful Planning, Journal of Architecture and Life, 2(2): 253-264 (2017)

12. M. M oazzami, J. Ruwanpura, G. J ergeas, Conversion method for applying convertible contracts in oil and gas project, Procs 4th Construction Specialty Conference, Montréal, Canada (2013) 